Animal Health Research Institute

Assiut Regional Laboratory.

\title{
STUDY OF SOME INTESTINAL BACTERIAL INFECTION AND BLOOD BIOCHEMICAL CHANGES IN GOATS SUFFERING FROM ENTERITIS IN ASSIUT GOVERNORATE
}

(With 6 Tables)

\author{
By \\ A.M. MANAA and T.S. ABD EL-ALL* \\ * Dept. of Animal Medicine, Faculty of Vet. Med., Assiut University.
}

(Received at 9/10/2010)

دراسة بعض الإصابات البكتيرية والتغيرات البيوكيميائية فى الماعز المصابة

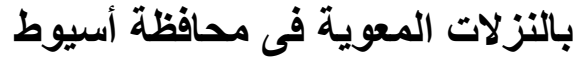

$$
\text { أحدد مددوح مناع ، ثروث سعيل عبل العال }
$$

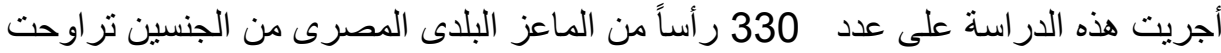

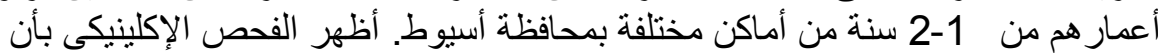

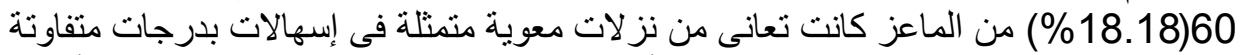

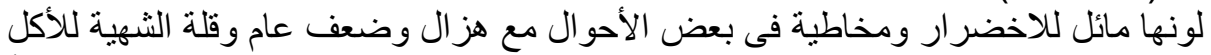

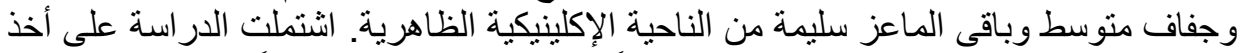

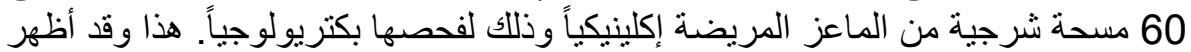

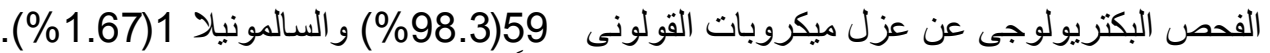

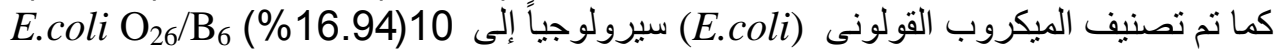
، E.coli $\mathrm{O}_{26} / \mathrm{B}_{60}(\% 6.6) 4$ ، E.coli $\mathrm{O}_{114} / \mathrm{B}_{16}(\% 10) 6$ ،

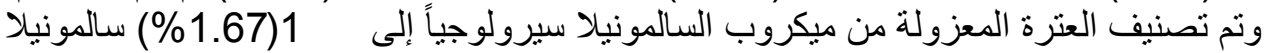

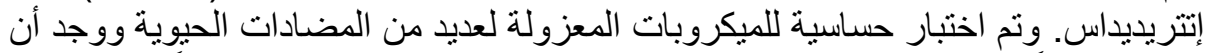

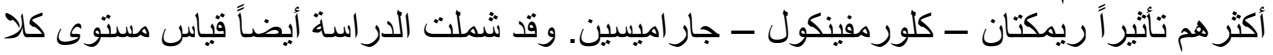

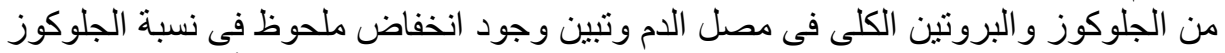

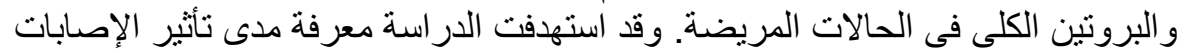

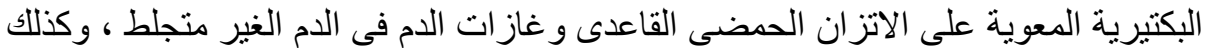

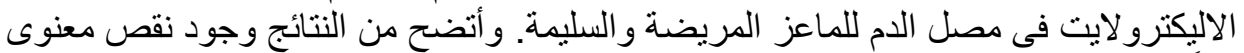

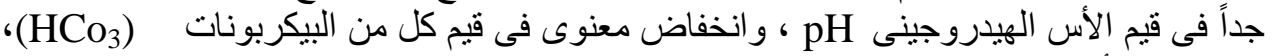

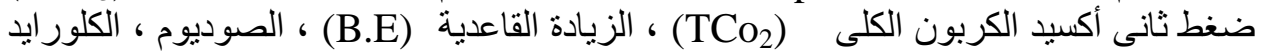

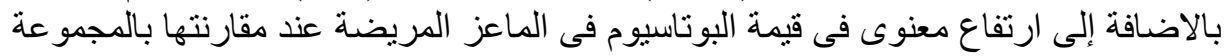




\section{SUMMARY}

The current study was carried out 330 Egyptian Balady goats from both sex, aged 1-2 years from different localitied at Assiut governorate. The clinical examination revealed that $60(18.18 \%)$ have enteritis with signs of diarrhea of different degrees, anorexia, loss of appetite, depression and slight emaciation and the remaining goats were apparently clinically healthy. 60 rectal swabs were taken from clinically diseased goats for bacteriological examination which revealed that the main isolates were E.coli 59(98.3\%) and Salmonella 1(1.67\%). The isolated E.coli strains were identified serologically into 10 strains and 39(66.10\%) untypable strains. The isolated salmonella strain were identified serologically into $1(1.67 \%)$ salmonella enteritidis. Antibiogram for the bacterial isolates revealed that the best sensitive antibiotics were rimactan, chloromphenicol and garamycin. Blood serum biochemical analysis in diseased cases showed significant $(\mathrm{p}<0.05)$ decrease in glucose and total protein levels in diseased cases. Also, the study aimed to knew the effect of bacterial enteritis on the blood gases, acid-base balance in heparinized blood and serum electrolytes of both clinically healthy and diseased goats. There were a marked decreased in mean values of blood $\mathrm{pH}$, significant decrease in values of $\mathrm{HCo}_{3}, \mathrm{TCo}_{2}, \mathrm{~B}$.E. sodium and chloride as well as significant increase in potassium level in clinically diseased goats when comparison with the control group.

Key words: Goat, Bacterial enteritis, Biochemical changes, Assiut Governorate.

\section{INTRODUCTION}

Goats are considered one of the most important farm animals and constitute one of the sources of meat for human consumption in Egypt.

Enteritis in young animals is a syndrome of great aetiological complexity. In addition to the influence of varied environmental, managemental, nutritional and physiological factors, but the numerous infectious agents are capable of causing enteritis in small animals (Snodgrass et al., 1986).

Bacterial enteritis is the most important cause of diarrhea in goats and lambs. Enterotoxigenic Escherichia coli (ETEC) is considered among the most prevalent causative agent of enteritis in goats (Gerald et al., 1992).

Coliform bacteria are commensals of the alimentary tract and can readily be identified on facecal culture. Enterotoxogenic E.coli strains are 
significants as a cause of diarrhoea in goats (Matthews, 1999) Enterogenic E.coli can also be isolated from both diarrhoeic and non diarrhoeic kids, (Meshram et al., 2009).

E.coli scour is an opportunistic disease associated with sloppy environmental conditions, poor sanitation and managemental practices. (Scott and Gessert, 1996).

Shaw (1971) has described a dysentery associated with E.coli. the author stated that the condition is usually seen where ewes and lambs were crowded together.

Causative agent E.coli has two different virulent strains, one type is associated with enterotoxigenic E.coli, which has two virulen factors responsible for diarrhea. E.coli is causative agent of white scour in goat (Bhat et al., 2008). Animals suffering from white scour have severe colitis characterized by abdominal pain, pasty faeces, and severe enteritis which may culminates to death due to severe dehydration (Radostits et al., 1995).

E.coli while as a normal gastro-intestinal inhabitant is also associated with a variety of pathological conditions in animals (Smith, 1965).

Salmonellosis cause acute diarrhoea in older goats and kids (Matthews, 1999).

Salmonella enteridis produces enterotoxins which are invasive to cause inflammatory change within the intestine leading to diarrhoea.

Bacterial enteritis remains the most common clinical problem in the goats (Meshram et al., 2009).

Salmonella typhimurium and salmonella enteritidis were also reported to be associated with some outbreaks of diarrhoea in adult goats and kids (Bulgin and Anderson, 1981).

Also Blackwell (1983) stated that salmonella enteritidis and salmonella typhimurium were frequently reported to be the cause od enteritis in kids, lambs, adult sheep and goats.

Many diseased conditions of which digestive disturbances are of great importance, induce severe changes in serum glucose and total protein elvels which reflect the status of animal body (Kaneko and Cornelius, 1971).

Ruminants subjected to different types of metabolic disorders that originated more or less from digestive origin (Brobest, 1975).

Serious disorders of acid-base balance and serum electrolyte occur in association with some diseased conditions in sheep and goats (Coles, 1980). 


\section{The purpose of this study:}

1 - Isolation and identification of bacteriological causative agents responsible for enteritis in goats located at Assiut Governorate.

2 - Study the anti-bacterial susceptibility test of isolated bacteria.

3 - Study the effect of enteritis on some biochemical changes in blood serum of diseased goat $\mathrm{s}$ and the changes in values of acid-base balance, blood gases and electrolytes in goats.

\section{MATERIALS and METHODS}

A total of 330 balady goats of both sex aged (1-2) years were used in this study located in different localities at Assiut Governorate. $60(18.18 \%)$ out of them showed clinical signs of enteritis.

\section{Samples for bacteriological examination:}

60 rectal swabs were taken from clinical and diarrhoeic goats for bacteriological studies.

The rectal swabs were inoculated aseptically into nutrient broth at $37^{\circ} \mathrm{C}$ for $24 \mathrm{~h}$. and then subculture into the following media. Difico nutrient agar, 5\% sheep blood agar, MacConkey agar, SS agar and XID agar.

The isolates were identified according to the colonial morphology, the pigment production, microscopically by gram stain and biochemically according to Baily and Scott, (1974); Quinn et al. (1994).

Serological characterization of isolated strains of E.coli and salmonella were done.

Antibiotic sensitivity testing: The bacterial isolates were tested for their resistance using disc disc diffusion method occording to Bauer et al. (1966), while zones of inhibition were determined according to National Committee for clinical Laboratory Standards (NCCLS, 2002). The antibiotic discs used were chloramphenicol $(30 \mu \mathrm{g})$, amoxicillin $(25 \mu \mathrm{g})$, nalidixic acid $(30 \mu \mathrm{g})$, erythromycin $(15 \mu \mathrm{g})$, garamycin $(30 \mu \mathrm{g})$, netilmicin $(30 \mu \mathrm{g})$, tetracycline $(30 \mu \mathrm{g})$, rimactan $(30 \mu \mathrm{g})$, colistin $(10 \mu \mathrm{g})$ and neomycin $(30 \mu \mathrm{g})$. The diameter of inhibition zones were measured (in $\mathrm{mm}$ ) for each plate compared with the standard break points.

Blood samples with anti-coagulant (EDTA) were collected from control group and clinically diseased goats for blood gases and acid-base balance measurements using corning pH-blood gas analyzer Model 168. The analyses directly measured at $37^{\circ} \mathrm{C}$, blood $\mathrm{pH}$. carbon dioxide tension $\left(\mathrm{PCO}_{2} \mathrm{~mm} \mathrm{Hg}\right)$, oxygen tension $\left(\mathrm{Po}_{2} \mathrm{~mm} \mathrm{Hg}\right)$, bicarbonate $\left(\mathrm{HCo}_{3}\right.$ $\mathrm{mmoL} / \mathrm{L})$, total carbon dioxide $\left(\mathrm{TCo}_{2} \mathrm{mmoL} / \mathrm{L}\right)$ and base excess $(\mathrm{B} . \mathrm{E}$ $\mathrm{mmoL} / \mathrm{L}$ ). 
Another blood serum samples were collected for determination of glucose $\mathrm{mg} / \mathrm{dL}$ (Werner and Wielinger, 1970) and total proteins $\mathrm{g} / \mathrm{dL}$ (Weichselbum, 1946). These levels were estimated spectrophotometrically by using test kits supplied from Bio-Merieux/Lab. Reag. Prodi, France.

Serum $\mathrm{Na}$ and $\mathrm{K}$ were determined by using flame photometer (Corning Model 400) while chloride level was determined by using chloride meter analyzer (Corning Model 925 England).

Statistical analysis of obtained serum biochemical data was performed according to method of Kalton (1967) using t-test.

N.B.I would like to express my deep thanks to the department of biochemistry and microbiology, faculty of medicine Assiut El-Azhar University.

\section{RESULTS}

The most prominent clinical signs of diseased goats were loss of appetite, diarrhoea, depression and general weakness.

The obtained results were shown in Tables 1-6.

Table 1: Localities and percentages of clinically diarrhoeic goats.

\begin{tabular}{|c|c|c|c|c|c|}
\hline \multirow[t]{2}{*}{ Locality } & \multicolumn{2}{|c|}{ Sex } & \multirow{2}{*}{$\begin{array}{l}\text { No. of } \\
\text { examined } \\
\text { goats }\end{array}$} & \multicolumn{2}{|c|}{$\begin{array}{l}\text { No. of clinically } \\
\text { diseased goats }\end{array}$} \\
\hline & Male & Female & & No & $\%$ \\
\hline Bani-Adi & 30 & 80 & 110 & 28 & 25.45 \\
\hline Abnob & 50 & 70 & 120 & 20 & 16.67 \\
\hline Bani-Mor & 40 & 60 & 100 & 12 & 12 \\
\hline Total & 120 & 210 & 330 & 60 & 18.18 \\
\hline
\end{tabular}

Table 2: Isolated pathogens from bacteriologically examined rectal swabs from diarroeic goats.

\begin{tabular}{|l|c|c|}
\hline \multicolumn{1}{|c|}{ Bacterial isolates } & No & $\%$ \\
\hline E.coli & 59 & 98.3 \\
Salmonella & 1 & 1.67 \\
\hline Total & 60 & $100 \%$ \\
\hline
\end{tabular}


Table 3: Serological identification of isolated E.coli and Salmonella strains of diarrhoeic goats.

\begin{tabular}{|l|c|c|}
\hline \multicolumn{1}{|c|}{ Enteropathogenic } & No & $\%$ \\
\hline E.coli $\mathrm{O}_{26} / \mathrm{B}_{6}$ & 10 & 16.94 \\
E.coli $\mathrm{O}_{114} / \mathrm{B}_{16}$ & 6 & 10 \\
E.coli $\mathrm{O}_{2} / \mathrm{B}_{60}$ & 4 & 6.6 \\
Untypable E.coli strains & 39 & 66.10 \\
Salmonella enteritidis $\mathrm{D}_{1}$ & 1 & 1.67 \\
\hline
\end{tabular}

Table 4: Inhibition Zone diameter (IZD) of test antibiotics against isolates of E.coli and Salmonella.

\begin{tabular}{|l|c|c|}
\hline \multirow{2}{*}{\multicolumn{1}{|c|}{ Antimicrobial agents }} & \multicolumn{2}{c|}{ Isolattion } \\
\cline { 2 - 3 } & E.coli & Salmonella \\
\hline Amoxicillin $(10 \mu \mathrm{g})$ & $\mathrm{R}\left(<13_{\mathrm{mm}}\right)$ & $\mathrm{R}\left(<13_{\mathrm{mm}}\right)$ \\
\hline Naladixic acid $(30 \mu \mathrm{g})$ & $\mathrm{R}\left(<13_{\mathrm{mm}}\right)$ & $\mathrm{R}\left(<13_{\mathrm{mm}}\right)$ \\
\hline Colistin $(10 \mu \mathrm{g})$ & $\mathrm{R}\left(<8_{\mathrm{mm}}\right)$ & $\mathrm{R}\left(<8_{\mathrm{mm}}\right)$ \\
\hline Erythromycin $(15 \mu \mathrm{g})$ & $\mathrm{R}\left(<13_{\mathrm{mm}}\right)$ & $\mathrm{R}\left(<13_{\mathrm{mm}}\right)$ \\
\hline Neomycin $(30 \mu \mathrm{g})$ & $\mathrm{R}\left(<10_{\mathrm{mm}}\right)$ & $\mathrm{I}\left(<15_{\mathrm{mm}}\right)$ \\
\hline Garamycin $(30 \mu \mathrm{g})$ & $\mathrm{S}\left(>15_{\mathrm{mm}}\right)$ & $\mathrm{S}\left(>15_{\mathrm{mm}}\right)$ \\
\hline Teracycline $(30 \mu \mathrm{g})$ & $\mathrm{R}\left(<14_{\mathrm{mm}}\right)$ & $\mathrm{R}\left(<14_{\mathrm{mm}}\right)$ \\
\hline Chloramphenicol $(30 \mu \mathrm{g})$ & $\mathrm{S}\left(>18_{\mathrm{mm}}\right)$ & $\mathrm{S}\left(>18_{\mathrm{mm}}\right)$ \\
\hline Netilimicin $(30 \mu \mathrm{g})$ & $\mathrm{S}\left(>22_{\mathrm{mm}}\right)$ & $\mathrm{S}\left(>22_{\mathrm{mm}}\right)$ \\
\hline Rimactan $(30 \mu \mathrm{g})$ & $\mathrm{S}\left(>20_{\mathrm{mm}}\right)$ & $\mathrm{S}\left(>20_{\mathrm{mm}}\right)$ \\
\hline
\end{tabular}

R: Resistance

I: Intermediate inhibition zone

S: Sensitive

Table 5: Blood serum bciochemical values in apparently healthy (Control) and clinically diseased goats.

\begin{tabular}{|l|c|c|}
\hline \multicolumn{1}{|c|}{ Parameters } & $\begin{array}{c}\text { Healthy goats }(10) \\
\text { mean } \pm \text { SE }\end{array}$ & $\begin{array}{c}\text { Diseased goats }(20) \\
\text { mean } \pm \text { SE }\end{array}$ \\
\hline Glucose $(\mathrm{mg} / \mathrm{dL})$ & $60.98 \pm 0.5$ & $58.66 \pm 1.25^{*}$ \\
Total protein $(\mathrm{g} / \mathrm{dL})$ & $6.37 \pm 0.64$ & $5.83 \pm 1.03^{*}$ \\
\hline
\end{tabular}

*: Significant $(\mathrm{P}<0.05)$

**: Highly significant $(\mathrm{P}<0.01)$ 
Table 6: Values of blood gases, acid-base balance and electrolytes in clinically healthy and diarrhoeic goats.

\begin{tabular}{|l|c|c|}
\hline \multicolumn{1}{|c|}{ Parameters } & $\begin{array}{c}\text { Clinically healthy } \\
\text { mean } \pm \mathrm{S} . \mathrm{E}\end{array}$ & $\begin{array}{c}\text { Diseased goats (10) } \\
\text { mean } \pm \mathrm{S} . \mathrm{E}\end{array}$ \\
\hline $\mathrm{pH}$ & $7.441 \pm 0.040$ & $7.250 \pm 0.071 * *$ \\
$\mathrm{PCo}_{2} \mathrm{mmHg}$ & $38.243 \pm 3.987$ & $35.532 \pm 3.817$ \\
$\mathrm{Po}_{2} \mathrm{mmHg}$ & $32.236 \pm 6.763$ & $33.573 \pm 6.175$ \\
$\mathrm{HCo}_{3} \mathrm{mmoL} / \mathrm{L}$ & $26.573 \pm 2.813$ & $19.620 \pm 4.003^{*}$ \\
$\mathrm{TCo}_{2} \mathrm{mmoL} / \mathrm{L}$ & $28.180 \pm 3.296$ & $21.163 \pm 4.256^{*}$ \\
$\mathrm{B.E} \mathrm{mmoL/L}$ & $3.140 \pm 2.933$ & $-2.240 \pm 5.575^{*}$ \\
$\mathrm{Na}^{+} \mathrm{mmoL} / \mathrm{L}$ & $154.710 \pm 6.867$ & $139.530 \pm 2.351^{*}$ \\
$\mathrm{~K}^{+} \mathrm{mmoL} / \mathrm{L}$ & $5.43 \pm 0.363$ & $6.610 \pm 0.126^{*}$ \\
$\mathrm{CL} \mathrm{mmoL/L}$ & $106.600 \pm 357$ & $97.400 \pm 2.675^{*}$ \\
& \multicolumn{2}{|c}{} \\
\hline
\end{tabular}

*: Significant $(\mathrm{P}<0.05)$

**: Highly significant $(\mathrm{P}<0.01)$

\section{DISCUSSION}

Various degrees of diarrhoea, depression, weakness and loss of weight were noticed during clinical investigation of diarrhoeic goats. Diarrhoea in some cases was offensive, semifluid, watery, yellowish, containing mucous and sometimes tinged with blood. In others, faeces were foeted, profuse, caly to yellowish or grayish. These findings support many of previous investigations in a similar condition (El-Daml et al., 2001 and Meshram et al., 2009). Mean while Abd-El-Mawla and Ahmed (2002) recorded that growth rate is reduced and weight gain loss could occur in older goats and sheep but diarrhoea is a common condition affecting newly born lambs and goats.

Table 1 recorded 60(18.18\%) goats out of 330 had diarhoeic signs while El-Daml et al. (2001) mentioned that 124(66.66\%) of goats from total 186 showed clinical signs of diarrhoea. Meanwhile Abd-El-Mawla and Ahmed, (2002) recorded that 77(77\%) diarrhoeic goats from 100 clinically healthy ones.

The result in table 2 recorded that E.coli is the dominant bacterial infection among diarrhoeic goats. This came in agreement with data obtained by El Daml et al. (2001). Also, Samaha et al. (2002) who recorded that E.coli and salmonella were the most common bacterial isolates from diarrhoeic goats. The authors mentioned that 29(58\%) E.coli and $1(2 \%)$ salmonella sp. from total 50 rectal swabs of goats with diarrhoeic signs. On the other hand, El Daml et al. (2001) mentioned that 
E.coli was isolated from 22 cases of diarrhoeic goats (17.74\%) out of 124 cases of goats of clinically signs of diarrhoea and 7(5.64\%) salmonella sp. were isolated.

Abd-El-Mawla and Ahmed, (2002) recorded that E.coli was isolated $32(32 \%)$ from 100 diarrhoeic goats and 2(2\%) salmonella typhimurium. The results recorded in Table 3 revealed that the enteropathogenic E.coli $\mathrm{O}_{26} / \mathrm{B}_{6} ; \mathrm{O}_{114} / \mathrm{B}_{16} ; \mathrm{O}_{26} / \mathrm{K}_{60}$ ) were the main microbiological cause of enteric infections in diseased goats. This result agreed with that previously reported by Amer et al. (1985) and Snodgrass et al. (1986). The mechanism by which the organisms may produce the disease is the toxins production. These toxins may be entro or endotoxins. The entro-toxin is produced by entero-pathogenic E.coli proliferating in the anterior small intestine causing hypersecretion through intestinal epithelium. Some pathological changes in the jejunum and ileum, and diarrhoea. Endotoxin is thought to act either directly or indirectly by means of an anaphylactic reaction which could produce diarrhoea, various forms of enteritis and oedema disease (Sojka, 1971).

However there are some entero-pathogenic E.coli which do not produce toxin, but they adhere to surface of the enterocytes of large intestine, and the affected calves pass bright red blood in diarrhoeic faeces (Hail, 1985). In this study salmonella infection formed the second main cause of enteritis in diseased goats (Table 3). Our results agreed with Meshram et al. (2009) who recorded that bacteriological examinations of goats suffering from enteritis were found to be positive for either Salmonella enteritidis and Escherichia coli (E.coli). Johnston et al. (1976) mentioned that Salmonella causes the main pathological lesion in the from of inflammation of the ileum, while the main clinical manifestations were loss of apetite, depression, dullness and diarrhoea. The faeces was watery and contained mucous and clots of blood.

Antibiogram for the isolates of enterotoxigenic E.coli and salmonella revealed that the best sensitive antibiotics are rimactan, chloramphenicol, garamycin and netilimicin (Table 4). This result agreed with previously reported by Monica (1985) and Amar et al. (1993). On the other hand, Sayed et al. (2001) recorded that all E.coli strains in enteric sheep were sensitive and susceptible to both tobramycin and enroflaxacin. Also El-Daml, (2001) mentioned that all strains of E.coli and salmonella in diarrhoeic kids were sensitive to ciprofloxacin and Enrofloxacin, gentamycin and chloramphenicol. These results did not agree with data obtained by Abd-El-Mawla and Ahmed (2002). Those authors mentioned that streptomycin, gentamycin and neomycin were the best drugs for 
treatment of E.coli in diarrhoeic lambs and goats while gentamycin, ampicillin and chloramphenicol were the best drugs for salmonellosis.

Blood serum biochemical analysis (Table 5) declared that values of glucose and total protein levels in clinically healthy goats agreed with the data obtained by Meshram et al. (2009). In addition there were significant decrease $(\mathrm{p}<0.05)$ in glucose and total protein in goats suffering from enteritis when compared with clinically healthy ones. These data were generally supported by Meshram et al. (2009). The obtained hypoglycaemia may be due to the lack of intestinal absorption in case of enteritis (Coles, 1967). Mottelib, (1972) attributed such decrease in serum glucose level found in calves suffering from E.coli enteritis is due to the alteration in tissue metabolism caused by decreased blood flow and oxygenation. Another explanation has been given by Madison (1964) which attributed it to be due to the elevation of the ketone bodies in case of gastro-enteritis, and such elevation in blood ketones which consequently led to depression of the blood glucose. There was a significant decrease $(\mathrm{p}<0.05)$ in total protein in diarrhoeic goats when comparison with control healthy ones. These obtained data were in agreement with Meshram et al. (2009). Coles (1986) attributed the reduction of proteins to the anorexia of the diseased goats and the inability of their liver to synthetize protein.

Also, West et al. (1968) and Doxey (1971) suggested that certain bacteria or bacterial toxins causes increased capillary permeability and permit the escape of plasma proteins in tissues, so the osmotic pressure of proteins is increased in the tissue fluids and at the same time was decreased in the blood. Meanwhile Amer et al. (1993) reported that there is a significant decrease in glucose level but there is no significant change in total protein in calves with bacterial enteritis.

Amer et al. (1985) and Hassan et al. (1985) detected the predominance of entero pathogenic E.coli as the main cause in the pathogenesis of enteritis in calves at Upper Egypt. Salmonella sp. are considered mainly as primary organisms in case of enteritis in calves.

Evaluation of acid-base status and serum electrolytes level of the patient, are of great importance, as they provide the necessary information that will lead to greater understanding of the nature of the disease process, and guide line to the way of therapy. Serious disorders of acid-base balance occur in association with some diseased conditions in goats and sheep (Radostits et al., 1995).

In Table 6 the values of $\mathrm{pH}, \mathrm{PCo}_{2}, \mathrm{PO}_{2}, \mathrm{HCo}_{3}, \mathrm{TCO}_{2}$ and B.E. as well as $\mathrm{Na}^{+}, \mathrm{K}^{+}$and $\mathrm{CL}$ in clinically healthy goats are nearly similar to results obtained by Ali, (1985). In clinically diarrhoeic goats where highly significant $(\mathrm{p}<0.05)$ decrease in values of $\mathrm{pH}$ and significant decrease 
$(\mathrm{p}<0.05)$ in values of $\mathrm{HCo}_{3}, \mathrm{TCo}_{2}$ and excess (B.E.). On the other hand, there were significant decrease $(p<0.05)$ in both $\mathrm{Na}^{+}$and $\mathrm{Ct}$ while significant increase $(\mathrm{p}<0.05)$ in $\mathrm{k}^{+}$level in diseased goat. These results agreed with the results obtained by El-Sebaie et al. (1988). The drop of $\mathrm{pH}$ and base excess indicated more or less the occurrence of metabolic acidosis (Haskins, 1983). The significant drop in the $\mathrm{HCo}_{3}$ value in enteric group is mainly due to the loss of $\mathrm{HCo}_{3}$ with intestinal secretion through faeces. It was a constant finding that any alteration in $\mathrm{HC}_{3}$ was usually accompanied with the change in the concentration of $\mathrm{TCo}_{2}$ because the $\mathrm{TCO}_{2}$ values were calculation dependant.

The results of $\mathrm{Na}^{+}, \mathrm{K}^{+}$and $\mathrm{Cl}$ are nearly similar to results recorded by El-Sebaie et al. (1988) who mentioned that there were significant drop in $\mathrm{Na}^{+}, \overline{\mathrm{Cl}}$ values and significant increase in $\mathrm{K}^{+}$value in calves suffering from enteritis and such variations due to great loss of sodium $\left(\mathrm{Na}^{+}\right)$and

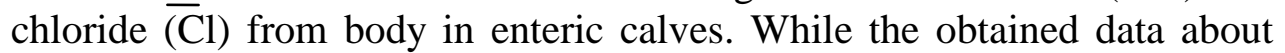
electrolytes did not agree with results obtained by Abou-El-Ela (2008), where in significant changes in both potassium and chloride occurred in enteritis of goats. On the other hand, primary metabolic acidosis may occur in animals during enteritis (Duks, 1964). Metabolic acidosis varing from moderate to severe was observed by Robert et al. (1990) in most calves suffering from diarrhoea concomitant with acidosis variations which were observed in serum chloride, sodium and potassium levels. In general our obtained data was in agreement with values previously recorded by Donawich and Baue, (1968), Saleh, (1983), El-Sebaie and Hassan (1984) and El-Sebaie et al. (1984).

\section{REFERENCES}

Abd-El, Mawala, Y.R. and Ahmed, A. (2002): Bacterial causes of diarrhea in newborn lambs and goat kids in Kafr El-Sheikh Governorate with special reference to E.coli. $10^{\text {th }}$ Sci. Cong. 2002, Fac. Vet. Med., Assiut., Assiut Univ., Egypt.

Abou El-Ela, A. (2008): Proteins and electrolytes in Desert goats suffering from internal parasites. Assiut Vet. Med. Vol. 54 No. 116 January 2008.

Ali, A.R. (1985): Acid-base balance, blood Gases and Haematological Changes Following Ruminal Dysfunction in Goats. M.V. Sc (general medicine and clinical laboratory Diagnosis). 
Amer, A.A.; Hassaan, N.K.; El-Sebaie, A.; Bayoumi, A.H. and Ibrahim, A.H. (1985): Studies on an outbreak of colibacillosis among Holstein Freiesian calves in the New Valley. Egypt: I-clinical, Heamatological, Aetiological and Pathological alterations. Assiut Vet. Med. J. Vol. 14, No. 27: 151-157.

Amer, A.A.; Sayed, A.M.; Manna, A.M. and El-Mileegy, A.H. (1993):

Microbiol respivatory disorders in buffaloe calves and the behavior of some serum biochemical constituents. Assiut Vet. Med. J. Vol. 28, No. 56, January 1993.

Baiely and Scott's (1974): Diagnostic Microbiology. $9^{\text {th }}$ Edition P. 420-422 (part 4).

Bauer, A.W.; Kirby, W.M.; Sherris, J.C. and Turck, M. (1966): Antibiotic Sensitivity testing by standardized method. Am. J. Clin. Pathol. 45: 493-496.

Bhat et al., (2008): Prevalence and virulence gene profiles of Shiga toxinproducing Escherichia coli and enteropathogenic Eshcerichia coli from diarrhoeic and healthy lambs in Inia. Small Ruminant Research 75(1): 56-70.

Blackwell, T.E. (1983): Enteritis and diarrhoea. Symposium on sheep and goat. Medicine Vterinary clinics of North America. Large animal practice Vol. 5 No. 3 November pp. 557-569.

Brobest, D. (1975): Evaluation of clinical disorders of acid base balance. J. Am. Vet. Med. Ass., 166 (4): 359-264.

Bulgin, M.S.; Andrson, R.C. (1981): Salmonellosis in goats. J. Am. Vet. Med. Assoc., 178: 7 720-723.

Coles, E.H. (1967): In: Veterinary Clinical Pathology. W.B. Saunders, Philadelphia and London.

Coles, E.H. (1980): Veterinary clinical pathology $3^{\text {rd }}$ edition W.B. Sunders company Philadelphia, London, Toronto.

Coles, E.H. (1986): A text bood of veterinary clinical pathology, $4^{\text {th }}$ Ed.

W.B. Sauders Co., Philadelphia, London Toronto. P. 220-260.

Donawick, W.J. and Baue, A.E. (1968): Blood Gases, Acid-base blance and Alveolar-Arterial Oxygen Gradient in Calves. Am. J. Vet. Res. Vol. 29 No. 22m: 163-167.

Doxey, D. (1971): Veterinary clinical pathology $1^{\text {st }}$ Ed. Bailliere, Tindall, London.

Dukes, H.H. (1964): The physiology of Domestic Animals. $5^{\text {th }}$ Ed, Bailllare, Tindall and Lox. London. Pp: 476-483.

El-Daml, A.M.; El-HHashem and Hatab, M. (2001): Diarrhoea in kids attributed to entero bacteria and cryptosoiridium. Assiut Vet. Med. J. Vol. 45 No. 89: April 2001. 
El-Sebaie, A. and Hassan, N.K. (1984): Some observations on acid-base blance and blood gases in association with diarrhoea in Egyptian buffalo calves. First. Vet. Scientific conf. Assiut.

El-Sebaie, A.; Hassan, N.K.; Mottielb, A. and Amer, A. (1984): Blood gases, acid-base balance and electrolytes in healthy sheep and goats. Assiut Vet. Med. J. 14 (27), 180.

El-Sebaie, A.H.; Ibrahim, A.H. and Manaa, A.M. (1988): Blood Gases and Acid base balance in Association with bronchopneumonia in calves. Assiut Vet. Med. J. Volume 19: No. 38, 1988.

Gerald, E. Duhamel; Rodney A. Moxley; Carol W. Maddox and Denis Erickson E. (1992): Enteric infection of a goat with enterohemorrhagic Escherichia coli. H. Vet. Diagn. Invest. 4: 197-200.

Hail, C.A.; Reynolds, J.; Chanter, N.; Morgan, J.H.; Person, K.R.; Debeny, I.G.; Bland, A.P. and Bridgel, J.C. (1985): Dysentery caused by Escherichia Coli (5 102-9) in calves by natural and experimental disease. J. Vet. Path. 22(2) 156-163.

Haskins, S.C. (1983): Current Vet. Therapy. $6^{\text {th }}$ Ed. Saunders company Philadelphia, London, Toronto and Mexico city.

Hassaan, Kn.K.; El-Sebaie, A. and Amer, A.A. (1985): Studies on an outbreal of colibacillosis among newly Holstein Friesien calves in the new valley, Egypt II Some serum biochemical and electrolyte changes. Assiut Vet. Med. J. Vol. 14 No. 27: 161-168.

Johnston, J.G.; Jones, R.T.; Jones, R.T. and Soulsby, E.J. (1976): Salmonellosis in calves due to lactose fermenting Salmonella typhimurium. Vet. Record 98 (3) 276-278.

Kalton, G. (1967): Introduction to statistical ideas from social scientistis. $2^{\text {nd }}$ Ed. Acid. Press. (London).

Kaneko, J.J. and Cornelius, C.E. (1970): Clinical biochemistry of domestic animals. $2^{\text {nd }}$ Ed. Acad. Press New York and London.

Kaneko, I.J. and Cornelius, C.E. (1971): Clinical biochemistry of domestic animals, $2^{\text {nd }}$ Ed. Vol. II, Academic press, New York and London.

Madison, L.L. (1964): Clinical and experimental action of kKetones on hepatic, glucose output and peripheral glucose utliziation. J. Lab. Clin. Med., 63:177.

Matthews, J.G. (1999): Diseases of the goat. $2^{\text {nd }}$ Ed. Black Well Science Ltd. United Kingdome 202: 225.

Meshram, M.; Ravikanth, K.; Maini, Si. and Rekhe, D.S. (2009): Treatment of clinical cases of bacterial enteritis in goat with new Polyherbal Anti diarrhoeal Formulation. Veterinary world Vol. 2, No. 4: April 2009. 
Monica, C. (1985): Medical laboratory manual for tropical countries Vpl. II: Microbiology. $1^{\text {st }}$ Ed. University Press, Cambridge.

Mottelib, A.A. (1972): A study on changes of blood in buffalo calves suffering from enteritis due to different causative agents. Thesis. Fac. Vet. Med. Assiut Univ. Assiut, Egypt.

"NCCLS" National Committee For Clinical Laboratory Standards (2002): Performance standards for Antimicrobial Disk and Dilution Susceptibility tests for bacteria isolated from Animals, Approved standard $2^{\text {nd }} E d$. NCCLS document M31-A2. NCCLS, Wayne, PA.

Quinn, P.J.; Carter, M.E.; Markey, B.K. and Carter (1994): Clinical Veterinary Microbiology. Mosby-Year Book Europe Limited. London, England. $1^{\text {st }}$ Ed.

Radostits, O.M.; Blood, D.C. and Gay, C.C. (1995): Vet. Medicine, A Textbook of diseases of Cattle, sheep, pig goats and Horses. $8^{\text {th }}$ Ed. Philadelphia Sydney, Tokyo, Toronto, pp 697.

Robert, W.; Bunnett, Elizabethlee-Lewandrowski, and Ent Lewandrowski, (1990): Electrolyte, Acid-base balance, In textbook of clinical laboratory medicine. Edited by McClatchey, D.K. $1^{\text {st }}$ Ed., William and Wilkins, Baltimore, Philadelphia, Hong Kong, London, Munich, Sydney, Tokoyo. Pp. 331-354.

Saleh, F.M.K. (1983): A contribution to the acid-base balance in normal and diseased sheep. M.V.Sc. Thesis, cairo, Univ., Egpt.

Samaha, H.A.; Droz, A.A.; Hagg, Y.N. and ENass, M. Abdou (2002): Small ruminants as a reservoir of certain bacterial and mycotic pathogens to man. Assiut Vet. Med. J. Vol. 46, No. 92, January 2002.

Sayed, A.M.; Abdel-Hafezz, M.M.; Thabet, A-El.R. and Bastawross, A.F. (2001): Studies on diarrhoea in lambs in Assiut Governorate. Assiut Vet. Med. J. Vol. 46 No. 91. October 2001.

Scott and Gessert, (1996): Watery mouth disease in lambs: biochemical parameters before and after treatment. Vet. Record, 139 (5): 117-118.

Shaw, W.B. (1971): Escherichia coli in newborn Lambs. Bv. Vet. J. 127: 214-219.

Smith, H.W. (1965): Observation on the aecliology of neonatal diarrhoea (Scours) in calves J. Pathol. Bacteriol., 84: 117.

Snodgrass, D.R.; Terzolo, H.R.; Sherwood, D.; Camphbell, I.; Menzies, J.D. and Synge B.A. (1986): Aetiology of diarrhoea in young caves. Vet. Record. 119(12) 31-34. 
Sojka, W.J. (1971): Enteric disease in new-born calves and lambs due to E.coli infection. Vet. Bulletin, 41(7) 509: 521.

Weichselbum, T.E. (1946): An accurate and rapid method for the determination of protein in small amount of blood serum and plasma Am. J. Clin. Path., 16: 40-49.

Werner, W.H.G. and Wielinger (1970): A colorimeteric method for glucose estimation. Z. Analyt. Chem. 252: 224.

West, E.S.; Todd, W.R.; Mason, H.S. and Van Bruggen, J.T. (1968): Text book of biochemistry $4^{\text {th }}$ Ed. The MacMillan Company, Ne 
Assiut Vet. Med. J. Vol. 57 No. 128 January 2011 